\title{
SIDE-EFFECTS OF THE GROWING TREND TOWARDS THE INSTITUTIONALIZATION OF MEDIATION
}

Humberto Dalla Bernardina de Pinho

Associate Professor, Rio de Janeiro State University. Adjunct Professor, Estácio de Sá University. Public Prosecutor in Rio de Janeiro.

Michele Pedrosa Paumgartten

Master in Law and Counsel in Rio de Janeiro.

\begin{abstract}
For some time, Europe, Brazil and the United States have been suffering from the systemic inefficiency of their Courts, with a significant impact on the guarantee of access to justice for their citizens, making alternative dispute resolution (A.D.R.) a constant presence in both civil and common law systems of jurisdiction. The upshot has been the institutionalization of ADRs, taking the form of a routine presence in codes of civil procedure, while their practice is connected to the courts. However, both institutionalization and the obligation to take part in mediation programs before or after starting the suit are exceptional measures, which must be adopted with caution. The experience of the European Union with its Directive, the Brazilian experience of inserting mediation into the project for the new Code of Civil Procedure and the use of mediation to overcome the conflicts arising from the serious mortgage crisis in the U.S.A. will be analyzed in this article, seeking to demonstrate that the progress and diffusion of ADRs does not necessarily entail a breach with their underlying foundation, and particularly with regard to mediation, the loss of its identity, for it to be inserted into the context of access to justice.
\end{abstract}

Keywords: Mediation - identity - mandatory - institutionalization.

\section{OPENING REMARKS}

Recent years have seen greater intensity in the search for alternative forms of dispute resolution, either to relieve the courts of the excessive burden imposed on them, or to afford better treatment of subjects beyond their reach. Methods revealed by negotiation, 
mediation, arbitration and their offshoots are considered an alternative ${ }^{l}$, given that they are cheaper, more consensual and so forth.

Widely popularized by the American courts, mediation has become the focus of a movement for its institutionalization ${ }^{2}$ into the judicial system, which has raised concern among scholars, who fear for its decadence, whereas it is known as an out-of-Court proceeding and a voluntary choice of the parties.

The growth of mediation in an institutional context may certainly expose and create greater interest in the process, but it is not the ideal mechanism for spreading the practice of mediation. Similarly, making it a mandatory procedure, whether pre-procedural or incidental, does not serve the interests of the parties; its convenience lays only in reducing the workload of the courts.

This paper will analyze the generalized institutionalization of mediation in the European Union, Brazil and the United States, and through critical reflection, will assess the paradoxical logic of making its practice mandatory by these legal systems.

\section{THE SPREAD OF INSTITUTIONALIZED MEDIATION}

The growth of mediation is much influenced by the context of the location where it takes place. In common law systems, such as the United States, Australia, Canada and England, mediation and other forms of ADR have been growing more quickly than in civil law systems, such as Brazil, Germany and Italy³.

1 "The use of these processes has become so increasingly pervasive that the 'alternative' of $A D R$ is increasingly being dropped in favor of such terms as 'complementary', 'additional', 'appropriate', or simply 'dispute resolution'. In addition, points out that 'Interestingly, some of mediator's greatest supporters are not in favor of dropping the 'alternative'from the description of ADR because they fear that by doing so, the process will become just like more traditional methods of dispute resolution - expensive, time-consuming, and not necessarily just." PRESS, Sharon. Institutionalization: Savior or Saboteur of Mediation? Florida State University Law Review. vol. 24, 1997, p. 903.

2 "Mediation was institutionalized in courts over the last twenty-five years, in part to provide access to justice that was otherwise unavailable in the civil justice system. Some scholars question whether this institutionalization offers anything that looks like justice." Also: "Though Pound offered several causes for this decline what we know today as "institutionalization" in the court system was the primary suspect. The very thing that made equity a system must, in the end, prove fatal to it. In the very act of becoming a system, it becomes legalized, and in becoming merely a competing system of law insures its ultimate downfall." NOLAN-HALEY, Jacqueline M. The Merger of Law and Mediation: Lessons from Equity Jurisprudence and Roscoe Pound. Cardozo Journal of Dispute Resolution, vol. 6, 2004, p. 57.

3 See: ALEXANDER, Nadja. Global Trends in Mediation. New York: Kluwer Law International, 2006. 
Quite often regarded as second-hand justice ${ }^{4}$, mediation is not a new procedure, although it is still incipient in the legal arena. Advantages of mediation are laboriously propagated, especially among those who consider it a useful tool for attenuating the gravity of the problem of access to justice. Proponents emphasize its ability to afford parties greater control over resolution of the conflict: as a result, the risk and the uncertainty of a court decision handed down by a judge selected at random to resolve the conflict is set aside, and also, the parties' ability to foster creative solutions that can be broader and better-suited to address the issues that underlie the conflict ${ }^{5}$.

This is why the mediated outcome is even more valuable and meaningful on disputes where the relationship between the parties is long-lasting and permanent. Confidentiality is another important factor, especially when we are faced with more sensitive issues, and as mediation does not mean the end of jurisdiction, if the mediation should fail, the parties would not be prevented from bringing before a judge the case still in dispute, so as to have it judged ${ }^{6}$.

Mediating does not mean the same thing for everyone. Centralizing the concept of mediation on the figure of the third party, much is said of his important role of facilitating an agreement as a specialist on the subject in dispute, or also of the task this impartial third party has to urge the parties towards a reassessment of their respective positions with greater accuracy faced with a conflict, so as to arrive at a solution by their own means.

In a simple and direct definition, mediation is the procedure whereby the litigants are aided by an impartial third party who will contribute to the search for a solution to the conflict. This third party does not have the mission of deciding (nor was he given authorization to do so $)^{7}$. He merely assists the parties in reaching a consensual

4 OWEN, Fiss. Alternative Dispute Resolutions Debated: Second-Hand Justice? The Connecticut Law Tribune. March 17, 1986.

5 Disputes involving a complex intersection of relationships have been called polycentric by Lon Fuller: "Wherever successful human association depends upon spontaneous and informal collaboration, shifting its forms with the task at hand, there adjudication is out of place except as it may declare certain ground rules applicable to a wide variety of activities." And the adjudication "cannot encompass and take into account the complex repercussions "that arise from the solution of a polycentric dispute. Most important within the scope of such disputes "it is simply impossible to afford each affected party a meaningful participation through proofs and arguments" FULLER, Lon. Mediation. Its Forms and Functions, CAL. L. REV. vol. 305, 1971.

6 PINHO, Humberto Dalla Bernardina de. A procedural Reading of human rights: the fundamental right to proper protection and the option for mediation as a legitimate route for the resolution of conflicts. Revista Juridica Universidad Interamericana de Puerto Rico, vol. XLIV, n 3, agosto-mayo, 2009-2010, p. 545/560.

7 PINHO, Humberto Dalla Bernardina de. Mediação: a redescoberta de um velho aliado na 
solution. Chiara $\mathrm{Besso}^{8}$, one of the great scholars of the matter in Italian law, describes the situation as follows: "è il procedimento nel quale un terço, il mediatore, facilita la comunicazione e la negoziazione tra le parti in conflitto, assistendole nel raggiungere un accordo, da loro volontariamente scelto;" Helena Munoz', commenting on the Spanish system, puts forward a similar notion.

However, the core quality of mediation is, in actual fact, the relational aspect that Lon Fuller ${ }^{10}$ had already mentioned in an article published over thirty years ago. It is moving towards resolution ${ }^{11}$ of the conflict, by means of a discursive practice, through dialog, and not coercive force, according to the regulatory idea of the possibility of consensus $^{12}$, wherein the legitimacy of the outcome finds its support in the very communicative process that originated it.

The idea of Luis Alberto Warat ${ }^{13}$, to whom the aim of mediation was not the agreement, but changing the persons and their feelings, seems to match the traditional concept of Lon Fuller. Only in this way would it be possible to transform and resize the effects of the conflicting situation, accompanying the premise according to which conflicts never disappear completely, but rather are only transformed and require management and monitoring to keep them under control.

Nevertheless, mediation has taken a challenging path in both common law and civil law systems ${ }^{14}$. The dizzy growth we find in the

solução de conflitos. In: Acesso à Justiça: efetividade do processo (org. Geraldo Prado). Rio de Janeiro: Lumen Juris, 2005, p. 108.

8 BESSO, Chiara. La Mediazione Italiana: Definizioni e Tipologie. Revista Eletrônica de Direito Processual. vol. VI, jul-dec. 2010, p. 33.

9 "La mediación es un procedimiento a través del cual un tercero imparcial ayuda a las partes en conflicto a llegar a un acuerdo. La esencia de la mediación que refleja esta definición es la autonomía de la voluntad de las partes: son las partes las que llegan a un acuerdo, libremente, $y$ auxiliadas por un tercero, que, consecuentemente, ha de ser imparcial. Por otra parte, esta perspectiva de la mediación se encuentra vinculada al conflicto que es objeto o puede ser objeto de un proceso". MUÑOZ, Helena S.. La mediación: método de resolución alternativa de conflictos en el proceso español. Revista Eletrônica de Direito Processual Civil. vol. III, p. 66-88, jan-jun. 2009.

10 "[...] the mediation has the capacity to reorient the parties towards each other, not by imposing rules on them, but by helping them to achieve a new and shared perception of their relationship, a perception that will redirect their attitudes and dispositions toward one another.' FULLER, Lon. op.cit.

11 See: RESTA, Eligio. Il Diritto Fraterno. Rome: Laterza, 2010.

12 OST, François. Contar a lei. As fontes do imaginário jurídico. Rio Grande do Sul: Unisinos, 2004, p. 151

13 WARAT, Luis Alberto. O oficio do mediador, v. 1. Florianópolis: Habitus, 2001, p. 31.

14 The civil - common law dichotomy has always inspired debate between the German historical school and its theory of codification as a counterpoint to the judiciary law of the utilitarian English. See: BOBBIO, Norberto. O Positivimo Jurídico. Lições de Filosofia do 
common law systems, such as Canada, England, the United Kingdom and United States, since the seventies ${ }^{15}$ contrasts with the reluctance of the countries that make up the civil law system to accept the practice of mediation as a means of resolving conflicts ${ }^{16}$. Irrespective of the differences in the stage of development of mediation, the concerns in countries which adopt the common law system or in those which adopt the civil law system converge on a common point: the use of mediation as the solution for the problems faced by the public administration, especially the Courts, in supporting the aim of access to justice.

What we observe is that besides the spread of the regulation of the ADR procedures, the mediation programs are being constantly incorporated to the Courts ${ }^{17}$, particularly where mediation is not widely used nor naturally sought by litigants. However, what is the impact of

Direito. São Paulo: Ícone, 2006.

15 Since the mid-1970's, "there has been a movement of de-legalization and deregulation, in a reaction against legal formalism in the institutional ambient and juridical culture as a whole (hard law vs. soft law), which guaranteed incentives to the expansion of community mediation; - investments by the federal government in Neighborhood Justice Centers, outside the Judiciary, which offered free or low-cost services of mediation to the public, seeking the empowerment of the parties and strengthening access to justice. Many of the present-day programs of mediation began informally as community mediation centers (as in the States of Florida and New York), with the mediators acting in the community; - only later on were they institutionalized with their migration to the judicial environment. There was then a greater concern with the legalization and state regulation of the alternate means of conflict solution within the Judiciary, in pursuit of standardization and incentives for the programs." GABBAY, Daniela Monteiro. Mediação \& Judiciário: condições necessárias para a institucionalização dos meios autocompositivos de solução de conflitos. 2011. Thesis for Doctorate in Law - Law School, University of São Paulo, São Paulo, 2011.

16 "It is useful to point out that not all common and civil law jurisdictions confirm these systemic patterns. The cases of the Netherlands and South Africa provide exceptions. The Netherlands, although stemming from a civil law tradition, has historically taken a proactive approach to legal reform, borrowing from both civil law and common law jurisdictions. Compared with most other civil law jurisdictions, the Netherlands has a well-established system of pre-trial conflict handling mechanisms. As a result, mediation developments in the Netherlands have been able to slide into the existing pre-trial structures and mediation has enjoyed success earlier in the Netherlands compared with other civil law countries. South African lawyers essentially apply a common law process to laws drawn from the civil codes of European jurisdictions. The system is a kind of uncodified civil law, which coexists with traditional community dispute management such as the makgotla. While the legal profession in South Africa has been hesitant to embrace the mediation of civil legal disputes going before the courts, the fall of the apartheid system has opened the entire spectrum of human rights, discrimination, constitutional, environmental and intergovernmental issues to ADR and put mediation very clearly on the South African map." ALEXANDER, Nadja. Global Trends in Mediation. ADR Bulletin. Vol. 6, n. 3, 2003.

17 See: PRESS, Sharon. Court-Connected Mediation and Minorities: A Report Card. Capital University Review. vol. 39, 2011, p. 819. 
the generalized institutionalization of mediation and its incorporation ${ }^{18}$ by the Courts? How does this emergence protect against mediation from becoming interlinked with adjudication? How long the state control of mediation programs that brought them into the jurisdictional realm on the argument of introducing and expanding the use of this method of ADR will subsist? Is it temporary? How will be like the return to its extrajudicial status after State output, supposing that this interference it will be temporary?

The expressive difference between the theory of mediation and these practices is the greatest challenge to be faced in the future in terms of the quality of mediation. And to face up to it, it is indispensable to redeem the rationale behind the foundations of mediation set out in the concept of Lon Fuller.

Achieving this quality does not mean anchoring the process of mediation in the submission of the parties to the rules of procedures, on the contrary: "to free themselves from the encumbrance of rules" to achieve "a relationship of mutual respect, trust, and understanding that will able them to meet shared contingencies without the aid of formal prescriptions laid down in advance."19

The institutionalization of mediation is an evident tendency. The carry out of mediation into the environment of the courts and its integration into the codes of civil procedure are heading towards a merger between regulation and mediation, making it an "important part of a new age of civil procedure." ${ }^{20}$ At first glance, its institutionalization may even mean an advance, but, in fact, it ends up by weakening the choices of the parties involved in the conflicts.

Mediation is one of the forms of dispute resolution that, as a rule, takes place out of court through private services, by the parties own initiative, although there is nothing that prevents it from taking place in a court ${ }^{21}$, enabled by a suspension of the lawsuit, for example, while

18 See: ALFINI, James J., et.al. What Happens When Mediation is Institutionalized? Ohio State Journal on Dispute Resolution, vol. 9, no. 307, 1994. Taking the same line: PRESS, Sharon. Mortgage Foreclosure Mediation in Florida - Implementation Challenges for an Institutionalized Program. Nevada Law Review. vol. 11, Spring 2011, p. 306.

19 On top of this, as well noted by Brian Ray: "In Fuller's conception, mediation has no role to play in the interpretation and enforcement of laws; that is the role of courts and the function of adjudication: '[O]nce a law has been duly enacted its interpretation and enforcement is for the courts; courts have been instituted, not to mediate disputes, but to decide them'". RAY, Brian. Extending the shadow of the law: using hybrid mechanisms to develop constitutional norms in socioeconomic rights. Utah Law Review. n. 3, pp. 797-842.

20 NOLAN-HALEY, Jacqueline M. The Merger of Law and Mediation: Lessons from Equity Jurisprudence and Roscoe Pound. Cardozo Journal of Dispute Resolution. vol. 6, 2004, p. 57. 21 "Sería más correcto hacer referencia a la mediación conectada con el Tribunal, tal como se denomina a esta clase de mediación en el sistema estadounidense (court-connected mediation), aunque en otros países de Europa en general se denomina mediación judicial, como en Bélgica 
parties will attempt to reach an agreement under mediation sessions.

However, the connected-court mediation is ceasing to be a mere option presented to the parties. The omnipresence of mediation in the Courts $^{22}$ and in the codes of procedure is a paradox, and presents a scenario that certainly strays from the traditional concept of mediation. The mediation loses its identity ${ }^{23}$ getting more and more resembling to adjudication, with rules of application and procedure. The judges are getting more and more mediators. A private procedure settling up in a public atmosphere controlled by an instrumentalist conception, which ends up serving only the administration of justice ${ }^{24}$.

\section{THE PATH TOWARDS MANDATORY MEDIATION: A WEAK REMEDY FOR THE CRISIS OF ACCESS TO JUSTICE}

The concern with access to justice arose in the mid-1970s, based on the study carried out by Cappelletti and Garth that led to a series of initiatives which developed a view to ensuring this right deemed basic and inherent to every Democratic State. Although part of this initial momentum to ensure access to justice has diminished in the course of the past thirty years in some societies, this concern has been a high priority at the present time.

The increasing demand for justice is a complex phenomenon, arising particularly from a social dependence on the Courts, either due to a culture of lawsuits ${ }^{25}$, (especially in countries with civil law systems), or due to state encouragement, which fearing the loss of its monopoly ${ }^{26}$,

distinguen, de la voluntaria, o en Francia de la convencional. El término más adecuado puede ser el de mediación conectada con el Tribunal o mediación intrajudicial, pues el término mediación judicial puede llevar a la errónea conclusión de que es el Juez el que lleva a cabo la labor de mediación". MUÑOZ, Helena S., op. cit.

22 An interesting expression is used by John Lande to describe the contemporary legal environment: "litimediation", in which the following reiterated practice takes place: "mediation is the normal way to end litigation." LANDE, John. How Will Lawyering and Mediation Practices Transform Each Other? Fla. St. U. L. Rev., 1997, pp. 839, 841.

23 See: NOLAN-HALEY, Jacqueline M. Mediation: The 'New Arbitration'. Harvard Negotiation Law Review, 2010, p. 3-54.

24 Id. Is Europe Headed Down the Primrose Path with Mandatory Mediation? North Carolina Journal of International Law and Commercial Regulation. vol. 37, 2012, p. 1-31.

25 See CHASE, Oscar G., American "Exceptionalism” and Comparative Procedure. American Journal of Comparative Law. Nov, 2001. Even though the text refers to the American culture of dispute resolution, it is valid for us to understand the use of the term culture and its concepts are suited to other societies. Also recommended: CHASE, Oscar G. Law, Culture, and Ritual: Disputing Systems in Cultural Context. New York University Press, 2005. Examining the issue from the standpoint of European law: TARUFFO, Michele. Cultura e processo. Rivista Trimestrale di Diritto e Procedura Civile. Milan: Giuffrè Editore, 2009. p. 63-92.

26 See. NOZICK, Robert. Anarquia, Estado e Utopia. Translation Ruy Jungman. Rio de 
spreads the idea that alone its Judiciary Branch is capable of providing an effective solution to conflicts, perceived when it promotes, for instance, the incorporation of ADRs to the Courts ${ }^{27}$.

Added to this are the reflexes caused by the international globalization ${ }^{28}$ of conflicts ${ }^{29}$ plus the fact that the rules or even common law are not suited to working with the concept of insoluble conflicts, or rather, conflicts that can hardly be resolved. The most that can be done is to monitor and undertake a work of follow-up, seeking to keep the dispute at acceptable levels of civility and sociability.

Yet the would-be solution goes no further than solving only the legal crisis, leaving moot other crisis of a different nature, and as these have not been settled jointly, the trend is towards their returning in the future, perhaps even under aggravated circumstances.

The political structures have always been attentive for the remedies (rules), but almost never to the conflicts causes, inducing to an increasing search for the Ombudsman State. Nonetheless, an unstoppable search for adjudicated solution faces a jurisdiction limited capacity. This limited capacity has shown that adjudication is sometimes ineffective, drags out the end of the lawsuit to an uncertain future, and do not fully resolve the problem at issue, since merely adds stability to a judicial decision. The effective conflict solution is beyond discussion.

Thus the unfitness of the judiciary to receive some cases and resolve them effectively is ratified.

Mediation has been carving out a role in this scenario as the cure for the inefficiencies of the systems of justice, and even though it is defined as a voluntary process, the label of a good alternative to adjudication has led many politicians and scholars to conclude

Janeiro: Zahar Editor, 1994.

27 "Sembra infati che la tendenza dominante nelle società asiatiche sia una sorta de litigation aversion che ha come naturale consenguenza di ADR, principalmente facendo ricorso alla mediazione e alla conciliazione. Questa preferenza viene solitamente spiegata con il riferimento alla persistenza - nello stato profondo della cultura asiatica - dell'ideale confunciano dell'armonia sociale che non dovrebbe essere turbata e messa in crisi dal ricorso ai tribunali". TARUFFO, Michele. Dimensioni transculturale della giustizia civile. Rivista Trimestrale di Diritto e Procedura Civille, Dec, 2007, p. 1067.

28 Eduardo Cambi stresses that the reflexes of this globalization are also felt in countries like Brazil, in spite of the lack of an effective community directive. "Arbitration, for example, has for some time now allowed decisions taken by arbitrators, in an international ambience, to be imposed on the decisions of national judges, fragmenting national law, as a form of responding to the requirements of the globalization of markets, as the costs, delay and appearance of highly-complex disputes make the court route less attractive." CAMBI, Eduardo. Neoconstitucionalismo e Neoprocessualismo. 2 ed, São Paulo: Revista dos Tribunais, 2010. p. 63.

29 See CANOTILHO, José Joaquim Gomes. Direito Constitucional. 6 ed, Coimbra: Almedina Editora, 1993. p. 18. 
that mediation should not only be incorporated to the jurisdictional environment, it also should be mandatory ${ }^{30}$.

Yet, in reality, won't we see those same mistakes from recent decades, in which access to the Judiciary Branch was promoted, with no regard for its limits? Is it rational forcibly submitting the parties ${ }^{31}$ to mediation? Might overvaluing mediation, in the long run, transform it into another ineffective method for solving conflicts, just as adjudication is today regarded by society? Do force the parties to participate in a process of mediation make them less liable to implement the settlement reached? Still, can mediation be worthwhile when it is mandatory?

It is important reinforce that mediation is an out-of-court procedure. It takes place before searching for state adjudication. However, there is nothing to stop the parties, having begun a lawsuit, deciding to go back on their positions and try, once more, the route of conciliation, either of their own free will or on the recommendation of a judge.

However, transforming it into an mandatory phase, either prior to the proceeding or incidentally, has the aim of serving merely statistical purposes, which are far from meeting the needs of the citizen. Mediation is not limited to silencing the other party, or that makes that the conflict "goes away". This does not allow the return to the status quo before the start of the conflict. The reason for mediation turns around the end of the controversy, the pacification rather than peace, setting aside the relational logic that is fundamental to it.

We have reached a point where mediation emerges from a paradoxical prospect: the unbridled search for institutionalization of mediation inserts its practice in Courts, brings rules to be followed by mediators, judges and other interested parties, and on top of this, imposes a timeframe for its terminating, predetermines the cases in which it must be used, and obliges the litigants to submit to the practice of mediation in certain cases.

All of this for remedying state inefficiency in the management of conflicts and the inevitable threat to the guarantee of access to justice. Nonetheless mediation acts as a weak remedy, almost a placebo, since in the early, the feeling of relief at the Judiciary is obvious, since mandatory mediation expresses a veritable barrier to stop litigants from

30 "Citizens of all counties accept regulations if they believe that as a result of that regulation "Society" will be better off. For instance in some countries bans on tobacco advertising are accepted because research has "proved" that smoking is bad for health. We pay for seatbelts in our cars (even though the government tells us we must) because research proves that seatbelts save lives." Mandatory Mediation. LC Paper N. CB (2)1574/01-02(01). Available at: <http:// www.legco.gov.hk >. Access on: Feb. 102012.

31 MONTELEONE, Girolamo. La mediazione "forzata". In: Judicium, p. 01-02. 2010. Available at the website: < http://www.judicium.it.> Access on: Nov. 202011. 
reaching the Judiciary.

It might seem that there is some benefit in obliging the parties to meet and discuss their dispute. The optimal result might be a solution mutually satisfactory and voluntarily agreed upon; the worst result, on the other hand, would be the failure in achieving a settlement and the pursue dispute to the Court, taking the form of discontent, additional costs and unnecessary delays, or further reaching any settlement as a result of ignorance of the process and of their own conflict.

Mediation is not a process suited to all cases, regardless of circumstance. It seeks to strengthen those who are less powerful through a balancing of power, more attentive listening, engendering options, the creation of awareness of the dispute, negotiation of solutions, removing the mask of demon or victim created by the other, allowing each side to choose the best alternative for a negotiated solution, reaching at the end, the consensus.

This entire voluntary process has as its essence the respect for the autonomy of will of the parties in participating on the process ${ }^{32}$, even admitting that mediation may be suggested by a judge. Thus any attempt to make it mandatory, prior or incidental to the lawsuit or with a term to end is quite unfitted.

The defenders of mandatory mediation may ask: how could anyone not wish to reach a mutually-beneficial settlement? It so happens that not everybody may be interested, or it may be that mediation is not really the best method to apply in the attempt to resolve that conflict.

Treating mediation like a magic potion ${ }^{33}$, believing that by making it mandatory, inserting it in the procedure codes and even placing it under the Judiciary's eyes will resolve the crisis of access to justice, reflects a distorted view of this guarantee and totally mistaken of the mechanism which, repeating, is essentially voluntary. The principle of autonomy of will, the first ground of mediation, relies on parties' freedom to be able to decide if and when mediation will be established,

32 We must always be alert to the fact that mediation will only be successful when in the option for mediation, the parties wish it, along with circumstances favorable to the mediation process, as well pointed out by Warren Winkler: "in certain cases the parties simply want a judicial determination of their rights, win or lose, not a mediated resolution. In that event, they are entitled to a trial and ought not to feel pressured in a settlement meeting to accept a compromise they are not interested in. ADR is not meant to subvert the conventional litigation process. Parties are entitled to have their rights decided in a court with appropriate procedural safeguards". WINKLER, K. Warren. Accès à la Justice: la mediation judiciaire. Canadian Arbitration and Mediation Journal. n. 16, p. 9-12. 2007.

33 PINHO, Humberto Dalla Bernadina de; PAUMGARTTEN, Michele. L'esperienza italobrasiliana nell'uso della mediazione in risposta alla crisi del monopolio statale di soluzione di conflitti e la garanzia di accesso alla giustizia. Revista de Direitos e Garantias Fundamentais FDV, n. 11, Aug. 2012, pp. 171-201. 
according to their interests and accord of wills.

The objections leveled against ADRs by Owen Fiss in "Against Settlement" arouse interest ${ }^{34}$. His arguments were centered on quality in the consent to reach a settlement based especially on the imbalance of forces (economic, business skills) between the participants in the process. For Fiss, a party's consent to an agreement, at disadvantage, would be the result of coercion. Updating the concern of the great jurist, his statements may be used perfectly as a warning as to the fragility, not of the outcome that may be obtained in a mediation, but of obliging the parties to take part in this process. It is the mandatory nature, in fact, that expresses an imbalance of forces and which may contaminate the outcome obtained in the mediation ${ }^{35}$.

The contemporary world requires the search for access to justice as a value, a justice thought through, not in the Christian manner whereby doing good or evil to the other is doing good or evil to oneself, but rather a justice that considers the counterpoise of more-or-less equal forces is the aim of ADR.

What is expected is not one more justice marked by rubbing out the distances and differences as if they had never existed; the new justice must have balance in its cellular nucleus. Being capable of balance, in fact, is already a manifestation of strength. The weak and the oppressed are incapable of raising themselves up to the one counterpoised against them. Acknowledgement of the other proves to be a noble and potent virtue, thus maintaining each one in his sphere of power ${ }^{36}$.

The aim ought be the dismantling of the traditional conception

34 FISS, O.M. Against Settlement, 93 Yale Law Journal 1073-90, May 1984.

35 Bret Walker and Andrew S. Bell underline the negative arguments against mandatory mediation "Such a forced process of mediation also has the potential to erode respect for the rule of law, especially if the power to order compulsory mediation is exercised frequently. It is not difficult to suppose that the power will be exercised frequently in times of pressure on courts institutionally to 'up their productivity', whatever this is meant to mean, and on judges individually, to deliver judgments expeditiously". WALKER, Bret; BELL, Andrews S.. Justice according to compulsory mediation. Bar News - The journal of NSW Bar Association. Spring. 2000, p. 7-8. And also: "The current regime recognizes the desirability of mediation as a means of dispute resolution without forcing parties down that route. There are, moreover, institutional mechanisms in place which encourage progress down that route. For example, it is now part of a barrister's duty to advise his or her clients at an early stage about the scope for means of dispute resolution in the alternative to litigation. Further, it is well known that many judges informally encourage litigants of the desirability of exploring dispute resolution by way of mediation. All of this is salutary and to be supported. The changes to be introduced by the Bill, however, are significant not just in practical terms but are radical and, in our opinion, most undesirable as a matter of principle." WALKER, Bret; BELL, Bell, op.cit.

36 PAUMGARTTEN, Michele. O processo interativo de construção de soluções como via de reabilitação do sistema vindicativo. Revista Eletrônica de Direito Processual Civil. vol IX. 2012. http://www.redp.com.br. 
of justice based more in the defense against a possible about-face of the winner than a concern with the conflict resolution, for a justice based on perception of the intents of others, relinquishing judgment, placing the individuals consciously in the game and committed with the negotiation. This conceals the sloth of those who are satisfied with the decision imposed, encompassed within a tradition of security, avoiding the mood of facing the consequences of the settlement.

It is about this security and resignation that we must avoid in the search for the real balance of forces. Therefore it will be in the agreement, once signed, which will give birth to the expression of truth, of peace, of opposition to anger, the wish for vengeance and punishment, inherent to mankind.

Along this line, and in the wake of the Green Book on Mediation ${ }^{37}$, in 2004 the European Parliament developed a project for a Directive concerning mediation, culminating in its publication in $2008^{38}$. In light of the Directive, the European member-states would be at liberty, at the time of transfer to their legal systems, to address the methods to be adopted in the installation of programs of mediation.

The following section will analyze the institutionalization of mediation by the European Union as well as the French, Spanish and

37 "In 2002, the European Commission issued a Green Paper on ADR [“Green Paper"] in civil and commercial law that specifically identified cross-border commercial disputes as an area in need of regulation. The purpose of the paper was to encourage the use of out-of -court dispute resolution as more appropriate in many cases than dispute resolution by judges or arbitrators. The Green Paper described ADR as a "political priority" for all EU institutions and launched a broad consultation process on how this goal could be achieved, although, it acknowledged that many member states had already passed legislation encouraging the use of ADR. As part of its consultation process, the Green Paper raised twenty-one questions about critical ADR issues including: confidentiality, consent, enforcement, mediator training, mediator accreditation and liability and the problem of prescription periods" NOLAN-HALEY. Jacqueline M. Evolving Paths to Justice: Assessing the EU Directive on Mediation. Proceedings of the sixth annual conference on international arbitration and mediation. Martinus Nijhof Publishers. 2011, p. $1-17$

38 "The Directive's foundations can be traced to a series of projects beginning with the Vienna Action Plan of 1998 which established mediation as a priority "particularly for family conflicts." Its foundations were further advanced at the Tampere European Council in 1999 that called for better access to justice, and for the creation of "alternative extrajudicial procedures" to be created by Member States. From 1998 through 2002 the Committee of Ministers of the Council of Europe adopted recommendations to promote mediation in family disputes, penal matters, and disputes with administrative authorities, and a Working Group was established to monitor the progress of these recommendations. A significant aspect of the Working Group's guidelines was its concern with the role of lawyers, judges, and legal educators in promoting ADR awareness. Several ADR programs were established to promote consumer access to justice, and the European Commission recommended that institutions involved in the consensual resolution of consumer disputes be influenced by the principles of impartiality, transparency, effectiveness and fairness". Ibidem 
German laws, published upon expiry of the deadline for transferring the Directive. This includes the Italian legislative decree, the first law to be published in the wake of the Directive, which besides opting for mandatory mediation, created procedural mechanisms whose constitutionality is questioned. The section will also examine the institutionalization of mediation by Brazil, and lastly, a reflection on the option for mandatory mediation made by some American states to resolve conflicts thrown up by the mortgage crisis.

\section{THE PRESENT DAY SCENARIO FOR MEDIATION IN EUROPE, BRAZIL AND IN U.S.A.}

A powerful wave of reforms has been promoted by various countries seeking to attach the ADR concept to the movement for access to justice, or, as defined by the European Parliament, access to suitable processes of resolution of individual and business disputes.

\section{A. THE WATCHWORD OF THE EUROPEAN DIRECTIVE: ENCOURAGE}

The movement for mediation in Europe got under way in the late 1990's. This came in the aftermath of the new era that emerged in the U.S.A. after the Pound Conference of 1976 which saw the birth of concepts such as the "multi-door courthouse." These ideas spread to Australia, Canada and New Zealand as far back as the 1980's ${ }^{39}$. The appeal for mediation was strong, as it was a process that brought in more advantages than disadvantages, such as lower costs compared to a judicial or arbitration proceeding, informality, flexibility and autonomy to reach a consensus.

Different models were developed in Europe. Some countries regulated mediation ${ }^{40}$ and it became common to find programs of mediation to resolve conflicts involving consumer rights ${ }^{41}$. This was

39 ALEXANDER, Nadja. Op. cit.

40 Poland, for example, was the first country in Eastern Europe to enact legislation on mediation in civil and commercial cases. Poland's law was much broader than the Directive which is limited to cross-border commercial disputes. See: PIECKOWSKI, Sylwester. How the New Polish Civil Mediation Law Compares with the Proposed EU Directive on Mediation, 61 DISP. RES. J. 67, 2006.

41 In the private sector, several provider organizations in continental Europe have encouraged mediation since the 1990s, while traditional arbitration providers added mediation to their list of services. In 1996 the U.S. based CPR Institute for Dispute Resolution published the Model European Mediation Procedures, and in 2001 the International Chamber of Commerce, a leading provider of arbitration services, issued ADR Rules making mediation the default choice of a dispute resolution process. See: NOLAN-HALEY, Jacqueline. op.cit., 2012. See 
until May 212008 when Directive 52, which arose from the fundamental recommendation launched in 1998 (98/257/CE) and in $2001(2001 / 310 /$ $\mathrm{CE})$, was published by the European Parliament. This triggered a policy that prioritized the consensual solution of conflicts that became a definitive part of the agenda for the European Judicial Area and obliged each member-state to reflect, insert or create legal texts contemplating mechanisms for the amicable settlement of conflicts. This generated a series of significant changes to the national systems of many memberstates.

Even though the Directive had a scope more restricted than that recommended by the Green Book on Mediation and even the 2004 Project for the Directive, it is undeniable that the objective of this intervention was to encourage countries, especially those countries with no tradition in the use of ADRs, to enshrine mediation in civil and commercial cases ${ }^{42}$ as an important step towards access to justice and towards the simpler and speedier resolution of conflict. Consequently, this tried to resolve the grave crisis of institutional justice looming over the greater part of the member-states.

Even though the rule, given its community-wide scope, had as its immediate focus the regulation of transnational conflicts, the European Parliament and the European Union understood that the adoption of mediation, even on the countries' internal scenario, would have numerous benefits. Among these were: greater agility in the solution of controversies, a lower outlay on costs, a greater willingness by the parties involved for spontaneous compliance, and preservation of the amicable relationship between the interested parties.

The Directive defines mediation as a voluntary process in which a third party assists two or more parties in dispute to reach a resolution for their difference; a functional definition that focuses on agreement as the end sought by mediation. The European Parliament opted for a general regulation when drafting the Directive. This was done specifically to respond to the complexity caused by the different languages and cultures within the EU, although it would appear to have been insufficient to promote a consensus among the member-states in

also: "French experience: Les Médiateurs de la Paix" MARTINS, NadiaI Beviláqua. ADR in the age of contemporaneity. Curitiba: Juruá, 2010, p. 271; Int'l Chamber of Commerce. ADR Rules of the Int'l Chamber of Commerce. Preamble and Article 5, available at http://www. iccwbo.org/court/adr/id4452/index.html.

42 The objective of the Directive is clear: "The objective of this Directive is to facilitate access to alternative dispute resolution and to promote the amicable settlement of disputes by encouraging the use of mediation and by ensuring a balanced relationship between mediation and judicial proceedings" EUROPEAN UNION. Directive 2008/52/CE, of May 212008. Official Gazette of the European Union, European Parliament and the Council, Brussels, May 24 2008. p 3-8. 
the transfer of the rule of the Directive to their internal systems as the existence of different visions of the subject is something inevitable.

\section{FRENCH LAW}

Prior to the Directive in France, by means of Decree 96-652 of 1996, the Code of Civil Procedure already provided for holding the total or partial mediation of a dispute in court and outlined some procedures integrated to the procedural rule. However, the European Directive calls for a broader approach to mechanisms for the amicable solution of conflicts, which has led to significant changes to the legal systems of the member-states, as mentioned above.

In compliance with the Directive, Decree 66 of $2012^{43}$ was published in France, which, while still representing timid progress in the handling of ADRs in the country, did establish the search for an amicable solution through mediation (which may be done by a natural person or legal entity), conciliation, or a participative process. However, it does not impose on the parties any procedural or pre-procedural phase.

The innovation introduced by the Decree is the participative proceeding. It was inspired by the Collaborative Law, which was common in countries such as the U.S.A., Canada, Australia and the United Kingdom. Pursuant to the Collaborative Law, parties seek an agreement to bring the conflict to a close according to the terms and conditions established in a contract signed with the participation of their attorneys, together. Communication is done through lawyers in an agreed upon form rather than with the aid of a neutral third party, though an expert may also provide assistance.

It is expected that conventional mediation or conciliation, as established in law, plus the new tool revealed by the participative proceeding, may drive the parties and French professionals even further towards resorting to these mechanisms as alternative means to jurisdiction, as proposed by the community Directive.

\section{SPANISH LAW}

In Spain, even though mediation showed a certain degree of development within the Autonomous Communities, Law 15/2005 (which regulated mediation prior to the Directive) was criticized for normative insufficiency, as it recommended that the Government should draft a bill on mediation based on the directives set forth by the European Union.

The Spanish Code of Civil Procedure integrated the practice of

43 Text available at $<$ http://www.legifrance.gouv.fr/affichTexte.do?cidTexte> Access on: Feb. 252012. 
mediation into family matters by means of Law $15 / 2005$, allowing the parties to request suspension of a case by mutual agreement which was allowed by the procedural law for a maximum of sixty days, a very tight schedule for mediating.

On March 05, 2012, after being subjected to stiff criticism for the delay in transferring the Directive to its internal system, the Spanish government published Decree No. 5/2012 44 , which regulates mediation in civil and business issues, excluding from its scope mediation within the public administration, in labor issues and consumer relations. Concerned with highlighting the potential for mediation, it encourages mediation as an alternative to jurisdiction or arbitration, putting it forward as an effective tool for the self-solution of conflicts and respecting the autonomy of will of the parties, demonstrated in titles II and IV of the Decree which establish the free decision of the parties in adhering to the procedure and the choice of mediator. It states objectively and clearly that mediation is voluntary, and even after beginning mediation, no-one is obliged to neither remain in the procedure nor conclude an agreement.

The Spanish law of civil procedure was also amended to allow suspension of the proceeding if the parties wish to mediate in the course of a lawsuit (stressing that in this case, the suspension will last as long as the mediation). It also, depending on the subject of the dispute, allowed the Court to invite the parties to participate in a mediation procedure with a prior informative session.

Besides highlighting the equality between the parties, the impartiality of the mediators, neutrality, and confidentiality, the Spanish lawmaker refrained from setting any deadline for holding the mediation, going no further than stating that the procedure shall be as brief as possible. The decree is quite right in not setting a deadline for concluding the procedure which we know cannot be foreseen as it depends on the emotional involvement of the parties with the case and the subject of the dispute, among other factors. This is left open, and however much brevity is demanded, it is certain that mediation will last as long as necessary to resolve the conflict.

The settlement reached by the parties may address all or part of the issues submitted to mediation, and may be formalized by a public deed to have the force of execution, or, if carried out in the course of a judicial proceeding, may be submitted for court ratification, with the consequent abandonment of the case.

The institutionalization of mediation in Spain operates at a reasonable level of legal transition, protecting the autonomy of will of the parties involved in a dispute without ruling out the possibility of the Court suggesting mediation to them, should it be considered suited

44 Text avsailable at Boletin Oficial del Estado: < http://www.boe.es/boe/dias/2012/03/06/pdfs/ BOE-A-2012-3152.pdf > Access on Mar. 072012. 
to the case. It states the technique of mediation coherently, respecting the nature of the mechanism, without adopting authoritarian procedural measures ${ }^{45}$.

\section{ENGLISH LAW}

The British experience is interesting, and also warrants analysis. In fact, the Civil Procedure Rules addresses the use of alternative means with Rule $1.4^{46}$ stating that the Court has the duty to actively manage cases, which includes, among other measures: "(e) encouraging the parties to use an alternative dispute resolution".

From this standpoint, the effectiveness of the jurisdictional measure means intervening (by means of a sentence of imposition), when necessary, as ultima ratio ${ }^{47}$, not least because failing to consider the use of "alternative means" may mean a waste, insofar as they not

45 As well stressed by item II of the exposition of motives of Law 5/2012: : "La mediación, como fórmula de autocomposición, es un instrumento eficaz para la resolución de controversias cuando el conflicto jurídico afecta a derechos subjetivos de carácter disponible. Como institución ordenada a la paz jurídica, contribuye concebir a los tribunales de justicia en este sector del ordenamiento jurídico como un último remedio, en caso de que no sea posible componer la situación por la mera voluntad de las partes y puede ser un hábil coadyuvante para la reducción de la carga de trabajo de aquéllos, reduciendo su intervención a aquellos casos en que las partes enfrentadas no hayan sido capaces de poner fin, desde el acuerdo, a la situación de controversia.".

46 "Civil Procedure Rules. Part One. Overriding Objective. (...) 1.4 Court's duty to manage cases (1) The court must further the overriding objective by actively managing cases. (2) Active case management includes: (a) encouraging the parties to co-operate with each other in the conduct of the proceedings; (b) identifying the issues at an early stage; (c) deciding promptly which issues need full investigation and trial and accordingly disposing summarily of the others; (d) deciding the order in which issues are to be resolved; (e) encouraging the parties to use an alternative dispute resolution (GL) procedure if the court considers that appropriate and facilitating the use of such procedure; (f) helping the parties to settle the whole or part of the case; (g) fixing timetables or otherwise controlling the progress of the case; (h) considering whether the likely benefits of taking a particular step justify the cost of taking it; (i) dealing with as many aspects of the case as it can on the same occasion; (j) dealing with the case without the parties needing to attend at court; (k) making use of technology; and (1) giving directions to ensure that the trial of a case proceeds quickly and efficiently" Text available for consultation at: http:/www.justice.gov.uk/guidance/courts-and-tribunals/courts/procedurerules/civil/menus/rules.htm, access on Dec. 282012.

47 "The CPRs state that the courts have observed more and more that legal proceedings must be the last option, and that suits must not be brought prematurely, when an agreement is still possible. Therefore, the parties must consider whether the alternative forms of dispute resolution are more suitable than litigation and, if such is the case, must make an effort to reach an agreement on which of the forms should be adopted." ANDREWS, Neil. (translation: Teresa Alvim Arruda Wambier). O Moderno Processo Civil: formas judiciais e alternativas de resolução de conflitos na Inglaterra, São Paulo: Revista dos Tribunais, 2009, p. 271. 
only ease access to justice, but also complement and enormously assist the procedural system, if properly employed ${ }^{48}$.

Along this line, as informed by Fernanda Pantoja ${ }^{49}$, despite precedents at the High Court restricting the possibilities of the parties' refusing the recommendation for mediation and going so far as to determine its being held, even when one of the parties had previously rejected this alternative ${ }^{50}$, the English Court of Appeal, in a May 2004 decision, limited the power of the High Court to impose an attempt at mediation on the litigants, arguing that obliging parties who do not wish to mediate amounts to a veritable obstruction of the right of access to justice. In the decision mentioned, the court stated that a compulsory system of mediation offends article 6 of the European Convention on Human Rights, which protects the universal right to a fair trial, in reasonable time, by an independent and impartial court ${ }^{51}$.

Thus, even without imposing mediation, there has been a significant reduction in the number of lawsuits, as we are informed by Chiara Besso $^{52}$, plus a considerable increase in the number of mediations ${ }^{53}$.

48 "To express this interaction between the public and private forms of civil justice, the author has elsewhere suggested (...) that a helpful metaphor might be 'Civil Justice's strand — consisting of ADR, including arbitration and mediation - and the other strand - the court process - are complementary and entwined. Together the two strands of the public court process and the alternative forms of private dispute resolution have considerable strength". ANDREWS, Neil. Mediation in England: organic growth and stately progress. Text not yet published and kindly ceded by the author at the time of his visit to the UERJ Law School in December 2011, p. 19/20. 49 PANTOJA, Fernanda Medina. Mediação Judicial, in: PINHO, Humberto Dalla Bernardina de (orga $\neg$ ni $\neg$ zer). Teoria Geral da Mediação à luz do Projeto de Lei e do Direito Comparado. Rio de Janeiro: Lumen Juris, 2008, p. 192.

50 "For example, in Hurst v. Leeming [2002] EWHC 1051 (Ch), the High Court stated that mediation should be refused only in exceptional circumstances. In Shirayama Shokusan Co. Ltd. v. Danova Ltd. [2003] EWHC 3006 (Ch), the High Court went so far as to order mediation over the objection of one of the parties" KIRMAYER, Kathryn e WESSEL, Jane. An offer one can't refuse: mediate. In The National Law Journal, Oct/2004, p. 1.

51 Halsey v. Milton Keynes General NHS Trust Steel v. (1) Joy \& (2) Halliday [2004] EWCA (Civ) 576. KIRMAYER, Kathryn e WESSEL, Jane. An offer one can't refuse: mediate. In The National Law Journal, Oct/2004, p. 1.

52 BESSO, Chiara (org). La Mediazione Civile e Commerciale, Torino: Giappichelli, 2010, p. 14.

53 'I.9. In the author's opinion, the most significant change is the recognition of mediation's potential as a means of reaching an agreement. Three new trends can be noticed here: I.10. First, the private market for dispute resolution in England has resorted to mediations in civil and commercial cases. The high cost of a lawsuit, caused mainly by the high fees of the attorneys has been one of the significant factors. (...) I.11. The second major change is that the English courts have shown great interest in holding mediations. (...). I.12. In third place, it has been recognized that agreements can be reached on different occasions, and result of different procedural stimuli or factors". ANDREWS, Neil. (translation Teresa Alvim Arruda 


\section{GERMAN LAW}

In Germany, meanwhile, with publication of the Gesetz zur Förderung der Mediation und anderer Verfahren de außergerichtlichen Konfliktbeilegung on July 25, $2012^{54}$, mediation did not become clearly mandatory, although it is required that upon filing suit, the party must state if there has been any prior attempt at conciliation.

Once the lawsuit has begun, the judge may propose alternative forms of resolving the conflict, in accordance with the case. He may send the parties to a private mediator or a conciliating judge (Güterichter), that is, a judge from the Court itself, who will receive special training to carry out the mediation, and who obviously cannot be involved with judgment of the case.

In the case of a settlement, court costs are reduced. The statute of limitations is suspended upon starting the process of mediation and the novelty concerns the qualification of the mediator. Prior to this law, mediators did not need to have specific qualification, and anyone could call himself a mediator. This situation has been partially modified, and though anyone can still call himself a mediator, to say that he is a "certified mediator" he must have attended an intensive 120-hour course. The aim is to ensure a minimum level of quality, as there were many problems with the services rendered by German mediators.

\section{B. THE WATCHWORD OF ITALIAN LEGISLATIVE DECREE NO. 28: OBLIGE}

The institutionalization of mediation by various EU countries follows a very similar formula. General lines are laid down and it is sought to attract mediation to the environment of the Court. Other member-states ${ }^{55}$, such as Bulgaria ${ }^{56}$ and Romania ${ }^{57}$, and even Germany recently, have sought to adopt, among other measures of encouragement, financial incentives if the parties are able to resolve by mediation a

Wambier). O Moderno Processo Civil: formas judiciais e alternativas de resolução de conflitos na Inglaterra, São Paulo: Revista dos Tribunais, 2009, p. 30.

54 Bundesgesetzblatt Jahrgang 2012 Teil I nr. 35, aausgegeben zu bonn am 25. July 2012. Available at: <http://www.bundesgesetzblatt.de>. Access on July 262012.

55 Greek law does not require consent for enforcement of the agreement. The Northern Ireland Access to Justice Review Report recommends that it be a condition of receiving legal aid in particular categories of cases that ADR options be considered and reasons given when they are rejected. NOLAN-HALEY, Jacqueline. op.cit., 2012.

56 See: Bulgarian Mediation Act/2004.

57 See: Romanian Mediation Act ( $\left.n^{\circ} 192 / 2006\right)$. 
dispute that would have been transformed into a lawsuit. However, Italy merits a special analysis, since in transferring the Directive, the country made use of procedural mechanisms that go beyond the idea of encouragement of the use of ADRs contained in the community-wide basic norm.

The Italian Parliament enacted Law No. 69 of June 18 2009, following the command of article 12 of Directive 2008/52/CE, which, besides addressing matters related to economic development and amendments to the Code of Civil Procedure, contained a provision on mediation delegating to the Government, and within a maximum of six months from the law coming into effect, publication of a legislative decree destined to standardize it in the civil and commercial sphere. Accordingly, on March 04 2010, Legislative Decree No. 28 was issued, which disciplines three types of mediation: mediazione facoltativa, mediazione concordata and mediazione obbligatoria ${ }^{58}$.

The regime of mediation adopted by Italy has extended far beyond the provisions of the Directive, and, as may be imagined, the most significant core which is causing the greatest impact is the obbligatoria modality, raised to the status of a condition for admissibility of the legal proceeding for a wide range of civil and commercial issues. If the parties go to court without following the mandatory procedure, the judge may send the parties to mediation, suspending the proceeding for four months, at the end of which the parties must have reached an agreement. If an agreement is being difficult to reach and if the mediator considers it appropriate, he may outline a proposal for a settlement.

Although the parties are theoretically free to reach the agreement, in the Italian decree, their freedom is somewhat mitigated, since if the suit filed is judged according to the terms of the agreement not settled, the Court may impose sanctions on the party who refused to accept the agreement, indirectly obliging the parties to reach an agreement to avoid suffering sanctions. Besides the breach of secrecy, setting a timeframe for the mediation and dressing up the mediator in the guise of a conciliator, penalizing a party who refuses to reach an agreement if the content is revealed in the grounds of the court sentence seems to us an excess of authoritarianism inserted into the Italian law that institutionalized mediation.

Faced with this, some professional associations have taken legal action against the Ministry of Justice and Ministry of Economic Development before the Lazio TAR, which decided in $2011^{59}$ that the doubts raised concerning certain provisions of D. Leg. No. 28/2010

58 DITTRICH, Lotario. Il procedimento di mediazione nel d. lgs. n. 28, del 4 marzo 2010 in $<$ http://www.judicium.it>. Access on October 202011.

59 The full text of the Decision is available at http://www.ilcaso.it. Consulted on September 152011. 
was not unfounded. These doubts were in regard to the excessive delegation stated in article 5, and the fact that mediation still at the prejudgment phase, expressing a condition for the admissibility of the case, effectively impedes access to justice ${ }^{60}$.

Besides the Lazio TAR, other courts such as the Court of Genova $^{61}$ and the Justice of Peace at Parma and Catanzaro ${ }^{62}$ have in recent decisions reinforced even further the unconstitutional profile of the law before the Italian Constitutional Court ${ }^{63}$.

While awaiting the statement from the Constitutional Court on the validity of some provisions of the decree, associations of Italian lawyers have been asking the courts not to apply the mechanism ${ }^{64}$, arguing that the judge, at the request of either one of the parties may admit the request, refusing to apply article 5 of the Decree, given its incompatibility with the European Charter of the Rights of Man ${ }^{65}$.

It is also important to stress the opinion issued by the European Commission in a response to the EU Court of Justice ${ }^{66}$. The remarks

60 VIGORITI, Vincenzo. Europa e mediazione. Problemi e soluzioni. Revista de Processo. n. 197. 2011, p. 248.

61 Tribunale di Genova. Sezione III Civile. N 4574/2011. Available at: < http://tribunale.genova. it>. Access on Mar 012012.

62 N. 2 Ordinanza del del 1 settembre 2011emessa dal Giudice di Pace di Catanzaro. Available at: $<$ http://www. gazzetaufficale.it.> Access on Mar 012012.

63 The hearing is set for October 23 2012, to be held at the Constitutional Court to analyze the mandatory nature of mandatory mediation, as informed in the Gazzetta Ufficiale No. 54, dated Dec. 282011.

64 It has also been quite common to request an obtain setting aside mandatory mediation in cases of in rem rights, especially adverse possession. News available at: < http://www.lider-lab. sssup.it/lider/it/mediazione/news $>$.

65 See the text published by the Organismo Unitario dell' Avvocatura Italiana, entitled: "Disappicazione dell'obbligatorietà della media conciliazione per contrasto della Corte dei Diritti Fondamentali dell'Unione Europea". Available at: < http://www.oua.it/Dottrina/Civile/ Civile.asp> Access on: Jan. 202012.

66 With regard for penalizing a party who refuses to close the agreement along the lines proposed by the conciliator: "non osta ad una normativa nazionale come quella oggetto della presente causa che prevede che la parte che ingiustificatamente non partecipa al procedimento di mediazione sia sanzionata con la possibilità per il giudice successivamente investito della controversia di desumere argomenti di prova dalla mancata partecipazione e con la condanna al pagamento di una somma corrispondente al contributo unificato dovuto per il giudizio. Tali sanzioni, non risultano tali da ostacolare o rendere particolarmente difficile l'accesso al giudice". However, is pondered, that in case of mandatory mediation: "osta ad una normativa nazionale quale quella oggetto della presente causa che assortisce il procedimento di mediazione di tipo obbligatorio di sanzioni economiche in grado di incidere sulla libertà delle parti di porre fine al procedimento di mediazione in qualsiasi momento e pertanto di limitare, in maniera sproporzionata, l'esercizio del diritto d'accesso al giudice". And recognizes that this measure goes beyond the policy of the Directive: "un sistema di mediazione quale quello istituito dal D.lgs. 28/2010, il quale prevede che il mediatore possa e a volte debba, senza 
of the Commission are particularly centralized on the mechanisms of sanctions ${ }^{67}$ stated in articles 11 and 13 of D. Leg. 28/2010.

Italy wants the unbridled adoption of mediation to alleviate the heavy volume of cases under way in its Courts ${ }^{68}$ and this would appear to be the paramount objective of the reform: to (ab)use mediation

che le parti possano opporvisi, formulare una proposta di conciliazione che le parti sono indotte ad accettare per evitare di incorrere in determinate sanzioni economiche, non é in grado di consentire alle parti di esercitare il diritto di decidere liberamente quando chiudere il procedimento di mediazione e pertanto non appare in linea con la ricerca consensuale dell'accordo di mediazione. Effettivamente tale meccanismo appare in grado di produrre un forte condizionamento delle scelte delle parti che sono spinte ad acconsentire alla mediazione (mettersi d'accordo amichevolmente o accettare la proposta del mediatore) e di conseguenza sono scoraggiate dall'introduzione del processo in sede giudiziaria. Tuttavia, nel caso in cui tale meccanismo opera nell'ambito della mediazione di tipo facoltativo, il condizionamento da esso prodotto non appare tale da incidere sull'esercizio del diritto d'accesso al giudice. Nelle ipotesi di mediazione facoltativa, infatti, sussiste sempre la possibilità per le parti di adire direttamente il giudice". Parere quello formulato dalla Commissione europea nella memoria consegnata alla Corte di Giustizia sul caso di media-conciliazione obbligatoria rinviato dal giudice di pace di Mercato San Severino alla Corte di Giustizia europea in vista della pronuncia pregiudiziale circa la compatibilità del D.Lgs. 28/2010 con la normativa europea. Full decision available at: http://www.mondoadr.it/cms/wp-content/uploads/commissione-Uesanzioni-conciliazione.pdf.

67 This makes more flexible the limitation imposed as a deadline for duration of the mediation: "non osta, in linea di principio, ad una normativa nazionale come quella oggetto della presente causa che prevede per l'esperimento della mediazione obbligatoria un termine di quattro mesi che in determinate circostanze sia destinato ad aumentare. Questa misura non appare tale da comportare un ritardo nell'introduzione e nella definizione di un successivo giudizio che possa essere tale da risultare manifestamente sproporzionato rispetto all'obiettivo di garantire una composizione più rapida delle controversie. Spetta, tuttavia, al giudice nazionale stabilire caso per caso se il ritardo che l'esperimento della mediazione obbligatoria comporta rispetto al diritto ad una tutela giurisdizionale effettiva non sia tale da comportare una compressione di questo diritto suscettibile di ledere la sostanza stessa del diritto". Regarding to the costs of the mediation, the European Commission concluded that: "osta, in linea di principio, ad una normativa nazionale come quella oggetto della presente causa che prevede una mediazione obbligatoria onerosa. Tuttavia, spetta al giudice nazionale stabilire caso per caso se i costi di una mediazione obbligatoria sono tali da rendere la misura sproporzionata rispetto all'obiettivo di una composizione più economica delle controversie". Idem.

68 Close to 9 million cases in 2007, some 5.4 million cases under way before the civil courts and another 3.3 million before the criminal courts. Of these 3.3 million, $1 / 3$ are initial proceedings while the rest are appeals. Compared to other European countries, the number of cases handled by the Italian civil court amounts to three times more than the quantity of cases before the French court, six times more than the load of the German court and five times more than the Spanish court. The number of lawsuits awaiting the first judgment (1.2 million) corresponded to twice the number of cases awaiting judgment in Germany, Spain and England together. O'CONNEL, Vanessa. Mandatory Mediation in Italy? Mamma Mia! The Wall Street Journal, March, 14, 2011. Available at: http:// wsj.com/law/2011/03/14/mandatory-mediation-in-italynot-if-the-lawyers-have-any-say/. 
to overcome a serious crisis in the civil courts, making it a tool for reducing the workload of the judges and cutting down the number of cases, not to mention the countless criticisms the country has received for failing to observe the guarantee of reasonable duration of cases, laid down in art. 6 of the European Human Rights Convention ${ }^{69}$.

\section{THE MEDIATION IN THE PROJECT OF THE NEW BRAZILIAN CIVIL PROCEDURE CODE}

In Brazil, mediation began to take legislative shape in 1998, but it was not until November of 2010 when the National Council of Justice issued Resolution No. $125^{70}$, that the activities of judicial conciliation and mediation were regulated ${ }^{71}$. Art. 1 of the Resolution institutes the National Judiciary Policy for handling conflicts of interest with the aim of assuring all of the rights to the solution of conflicts by appropriate means, making it clear that it behooves the Judiciary Branch to, besides providing a solution adjudicated by sentence, offer other mechanisms for resolving controversies, in particular the so-called consensual means, such as mediation and conciliation, as well as affording service and guidance to the citizen. To achieve these targets, the Courts are to set up as Permanent Center of Consensual Methods for Conflict Resolution

69 SCHENK, Leonardo. Breve relato histórico das reformas processuais na Itália. Um problema constante: a lentidão dos processos cíveis. Revista Eletrônica de Direito Processual, Rio de Janeiro, v. 2, p. 181-202, 2008. Available at: http://www.redp.com.br/edicao_02.htm. Access on: Sep. 122010.

70 Available at http://www.cnj.jus.br/atos-administrativos/atos-da-presidencia/323resolucoes/12243-resolucao-no-125-de-29-de-novembro-de-2010

71 "a) the right of access to justice, provided for in art. 5, XXXV, of the Federal Constitution, besides the formal version before the judiciary bodies, implies access to a fair legal system; $b$ ) at this point, it behooves the Judiciary to establish a public policy for the proper handling of legal problems and conflicts of interests, which occur on a wide and growing scale in society, so as to organize on a nationwide level not only the services rendered in legal proceedings, but also those that may be provided through other mechanisms for conflict resolution, in particular those of consensus, such as mediation and conciliation; c) the need to consolidate a permanent public policy of encouraging and enhancing the consensual mechanisms of conflict resolution; d) conciliation and mediation are effective tools of social peacemaking, solution and prevention of disputes, and their appropriate discipline in programs already implemented in the country has reduced the excessive institutionalization of conflicts of interests, the quantity of appeals and the enforcement of sentences; e) it is indispensable to stimulate, support and spread the systematization and enhancement of the practices already adopted by the courts; f) the importance and need to organize and standardize the services of mediation, conciliation and other consensual methods of conflict solution, to avoid disparities of orientation and practices, while also ensuring the proper execution of public policy, respecting the specific aspects of each segment of Justice." PINHO, Humberto Dalla Bernandina de. Mediação e o CPC Projetado. Revista de Processo. v. 207, p. 219, 2012. 
and install Judiciary Centers for Conflict Resolution and Citizenship.

With National Counsel of Justice Resolution No. 125 now in force, given the prospects of setting rules for judicial mediation in the Project of the New Code of Civil Procedure now taking shape, and also, faced with the heed to address issues concerning the integration between adjudication and forms of self-resolution, an Ante-project of a Law of Civil Mediation has been drafted. Following examination at the Consultancy of the Federal Senate in August 2011, a Senate Legislative Bill was presented, receiving the number $517^{72}$, working with concepts that are more up-to-date and better suited to Brazilian reality ${ }^{73}$.

However, the most relevant point, as we see it, lays in the clear option by the Commission of Jurists for the facultative and nonmandatory form of using mediation. It is important to stress this issue, as in the past there has been much controversy on this point, due to one of the most polemical aspects of the legislative proposal of 1998: the obligation to carry out this procedure in all fact-finding proceedings, save a few exceptions dictated by the project.

While the idea of imposing incidental mediation in certain cases is highly seductive, we do not believe it is the best solution, and the

72 The text may be consulted at the website of the Federal Senate, at http://www.senado.gov.br. 73 "Thus, for example, art. 2 states that: "mediation is a decision-making process conducted by an impartial third party, seeking to assist the parties to identify or develop consensual solutions". As to the modalities, art. 5 admits prior and judicial mediation, which in both cases may, chronologically, be prior, incidental or even subsequent to the procedural relationship. We quite often find references to prior and incidental, although we seldom find the regulation of subsequent mediation, although this is becoming more and more common (obviously, there must be an appraisal of possible impacts on the thing judged, which will not be analyzed in this work). Another innovation may be seen in the criterion used to conceptualize judicial and outof-court mediation. The option was for separating the classification from the site of holding the act, taking as a parameter the initiative of the choice. Thus, according to art. 6, "mediation will be judicial when the mediators are appointed by the Judiciary Branch, and out-of-court when the parties choose a private mediator or mediation institution". No objective restrictions were set as to the fitness of mediation. Suffice for the parties to wish it, by mutual agreement, and for the plea to be considered reasonable by the judge (art. 7). Mediation can never be imposed, nor can a refusal to take part in the procedure entail any sanction for either of the parties (2nd paragraph), while it falls to the judge, if the procedure is accepted by all, to decide on a possible suspension of the proceeding (4th paragraph), for a period no greater than 90 days (5th paragraph), unless agreed on by the parties with express court authorization. Also according to the text of the Project, the judge must "recommend judicial mediation, preferably, in conflicts in which it is necessary to preserve or recompose an interpersonal or social relation, or when the decisions of the parties entail material consequences for third parties" (art. 8). On the other hand, if mediation proves to be unsuited for settling that conflict, the act may be converted to a hearing of conciliation, if agreed upon by everyone (art. 13). So, without going into the specific issues of the Project, it is important to highlight the intent to standardize and make compatible the provisions of the New CPC and CNJ Resolution No 125, regulating the points that lacked legal handling" PINHO, Humberto Dalla Bernadina de, op.cit. 2012, p. 220. 
project of the new Code of Civil Procedure was quite right in resisting the siren's song of such a practice. In the wording currently available in the Project of the new CPC, we can identify the Commission's concern with the mechanisms of conciliation and mediation, specifically in articles 144 to 153 . The Project focuses, specifically, on mediation done within the structure of the Judiciary Branch. However, this does not rule out prior mediation or even the possibility of using other means for resolving conflicts (art. 153).

However, the institutionalization of mediation now entering Brazilian procedural law warrants a few brief remarks, due to certain peculiarities.

Brazilian experience in the area of conflict resolution has been gradually transformed, although the lawsuit-focused culture is a feature that leads to the judiciary being much sought-after, making it ever-more dysfunctional, slow, inaccessible to the excluded, ridden with red tape, inefficient and unpredictable ${ }^{74}$. Moreover, on the pretext of presenting other means for the solution of conflicts beyond the adjudicated solution, the Judiciary Branch takes upon itself the performance of mediation, impregnating it with the weight of state intervention, deepening the anachronism vis-à-vis the contemporary concept of ADR.

The spread of the use of this form is really the easiest and most comfortable way, when the ideal would be to have the methods for dispute resolution outside of jurisdiction presented in the universities to those who operate the Law, and made public generally in society, especially through the schools of basic qualification.

Educating society to resolve its own conflicts or to choose the best method for resolving them is an arduous task. This is especially true considering, however frustrating and inoperative the judicial services may be, it is difficult to break down a system which is comfortable because it is known and familiar even despite it being oppressive. Only education guides in relation to the rules of conduct and the values that will orient the option chosen; training and equipping individuals to distinguish between correct and incorrect reasons for preference and inclination in following the former and avoiding the latter, and leading individuals to internalize rules that will henceforth guide their practice ${ }^{75}$.

\section{MANDATORY MEDIATION AND THE U.S. MORTGAGE CRISIS}

The popularity of ADRs in common law countries is wellknown. The advent of Court-connected programs and the birth of

74 NALINI, José Renato. Os três eixos da Reforma do Judiciário. Revista do Advogado (AASP), n. 75, apr. 2004, p. 67.

75 BAUMAN, Zygmunt. Em busca da politica. Rio de Janeiro: Jorge Zahar editor, 2000. 
the concept of the multi-door courthouse coined by Frank Sander at the 1976 Pound Conference was to be a watershed in the history of $\mathrm{ADRs}^{76}$ in the United States and the harbinger of a new era in the area of conflict resolution. As a consequence, Court-Connected Programs and laws have been implemented at the federal and local level with the aim of stimulating the use of $\mathrm{ADRs}^{77}$, simultaneously triggering concern with the privatization of conflict resolution, as the public nature of the judgment and court decisions is a guarantee of protection of the individual's rights ${ }^{78}$.

The obligation to mediate ${ }^{79}$ has been debated now for many years by American scholars, and the thesis held is that the requirement is limited to submission by the parties to a process of mediation and not to reaching an agreement. Moreover, coercion into the use of mediation would serve to present the method to those unaware of the procedure, but who would be potential users of the practice. The arguments are always highly similar.

The Law and Public Policy Committee of the Society of Professionals in Dispute Resolution published a report in 1990 affirming that mandatory participation in a dispute-resolution procedure would, in certain situations, be appropriate. Federal legislation ${ }^{80}$ has followed the

76 See: STONE, Katherine V.W., Alternative Dispute Resolution. Encyclopedia of Legal History, Stan Katz, ed., Oxford University Press., 2004.

77 In 1983, Rule 16 of the Federal Rules of Civil Procedure was amended to exhort courts to consider the "possibility of settlement" or "the use of extrajudicial procedures to resolve the dispute" at pre-trial conferences. The Civil Justice Reform Act of 1990 also required every federal district court to consider court-sponsored ADR. In addition, the ADR Act of 1998 gave district courts the mandate to establish ADR programs and listed mediation as an appropriate ADR process. QUEK, Dorcas. Mandatory Mediation: An oxymoron? Examining the feasibility of implementing a court-mandated mediation program. Cardozo Journal of conflict resolution. vol. 11:479. 2010, p. 479-509

78 "Similarly, some critics urge that treating disputes as matters of individual, rather than public, concern eliminates important public accountability. Others argue that dispute resolution fails to serve an important educational function when it is privatized. Another common criticism is that the establishment of dispute resolution processes weakens the position of less powerful members of society". STERNILIGHT, Jean R., Is Alternative Dispute Resolution Consistent With the Rule of Law? De Paul Law Review, Vol. 56, , 2006, p. 569

79 See: SANDER, Frank E. A. Another View of Mandatory Mediation. DISP. RESOL. MAG., Winter 2007.

80 On this point it is worth taking a look at the "Alternative Dispute Resolution" Act, of 1988, in force in the United States. The main excerpts of the Act follow: "(...)(2) certain forms of alternative dispute resolution, including mediation, early neutral evaluation, mini-trials, and voluntary arbitration, may have potential to reduce the large backlog of cases now pending in some Federal courts throughout the United States, thereby allowing the courts to process their remaining cases more efficiently; (...) (b) AUTHORITY- Each United States district court shall authorize, by local rule adopted under section 2071(a), the use of alternative dispute resolution processes in all civil actions, including adversary proceedings in bankruptcy, in accordance 
same understanding, and, as a consequence, the Civil Justice Reform Act inserted mandatory mediation as part of the scenario of ADRs. The Courts have confirmed its legitimacy ${ }^{81}$.

The attachment to reasons such as efficiency and economy that similarly surround the U.S. programs of mandatory mediation has come in for stiff criticism. Studies show that the quantity of cases taken to court to challenge the validity and quality of the agreements obtained in mediation ${ }^{82}$ overcomes the logic of efficiency ${ }^{83}$, and that the cure for the inefficiency of access to justice has, in actual fact, become a barrier besides being anti-democratic ${ }^{84}$. It is important to stress that at no time are the benefits of mediation called into question; rather only the fact of its being imposed as a pseudo-facilitator of access to justice.

The central ideology of U.S. mediation is its voluntary nature ${ }^{85}$ based on self-determination ${ }^{86}$. However, programs of mandatory

with this chapter, except that the use of arbitration may be authorized only as provided in section 654. Each United States district court shall devise and implement its own alternative dispute resolution program, by local rule adopted under section 2071(a), to encourage and promote the use of alternative dispute resolution in its district. (...) SEC. 4. JURISDICTION. Section 652 of title 28, United States Code, is amended to read as follows: Sec. 652. Jurisdiction (a) CONSIDERATION OF ALTERNATIVE DISPUTE RESOLUTION IN APPROPRIATE CASES- Notwithstanding any provision of law to the contrary and except as provided in subsections (b) and (c), each district court shall, by local rule adopted under section 2071(a), require that litigants in all civil cases consider the use of an alternative dispute resolution process at an appropriate stage in the litigation. Each district court shall provide litigants in all civil cases with at least one alternative dispute resolution process, including, but not limited to, mediation, early neutral evaluation, minitrial, and arbitration as authorized in sections 654 through 658. Any district court that elects to require the use of alternative dispute resolution in certain cases may do so only with respect to mediation, early neutral evaluation, and, if the parties consent, arbitration. (...)”. Source: http://www.pubklaw.com/hi/105-315.html.

81 "After mediation was implemented as a cure for the inefficiencies of the justice system, mandatory mediation programs were adopted in numerous contexts, particularly for custody and divorce disputes”. NOLAN-HALEY, Jacqueline M. op.cit., 2012.

82 THOMPSON, N. Peter; COBEN, James R. Disputing Irony: A systematic look at litigation about mediation. 11 Harvard Negotiation Law Review. 43. 2006, pp. 73-89.

83 "Confidentiality may also be compromised, particularly when rules requiring good faith bargaining allow the mediator to report on what happened during mediation. Good faith bargaining requirements also can pressure parties to settle.Some parties who are referred to mediation may fear that if they do not settle, there will not be a favorable outcome from the judge". Ibidem

84 See: WELSH, Nancy A. The place of Court-Connected Mediation in a Democratic Justice System, 5 Cardozo Journal of Conflict Resolution 117, 2004.

85 See: NOLAN-HALEY, Jacqueline M. Mediation Exceptionality. Fordham Law Review, vol. 78 , n. 101, Nov. 2009.

86 "The Model Standards of Conduct for Mediators emphasize the importance of informed consent—-each party makes free and informed choices as to process and outcome." Ibidem. 
mediation ${ }^{87}$ have spread, adopting various models, from coercion in the guise of a court suggestion to submission to sessions of mediation and the institutionalized obligation as a condition precedent for judgment of the case.

The American explanation is that there is a difference between coercion into and coercion within mediation ${ }^{88}$. The Courts may require participation in sessions of mediation (front-end), yet they could not demand reaching an agreement or acceptance of a particular proposal (back-end), and thus mandatory mediation becomes an acceptable institution on the U.S. legal scene.

In recent years, the theme of mediation has taken a front seat for facing up to the conflicts arising from the grave mortgage crisis that has beleaguered the United States since $2008^{89}$. Although the laws to stimulate mediation are normally implemented at local level, in this case, given the magnitude of the problem, the Federal Government assumed a more proactive role, providing the States with funds to set up programs to promote negotiation between banks and borrowers, to prevent these coming before the Courts. The local governments and courts are in fact those best-suited to manage such programs of mediation, as they are more familiar with the social and economic nuances of their surroundings.

More than fifteen American States offer some type of mediation, while some of them ${ }^{90}$ have decided to force borrowers who face foreclosure to take part in sessions of mediation prior to the legal proceeding. Borrowers and creditors are informed of the need to attend a session of mediation. If the borrower fails to attend, he suffers no penalty, while the creditors may face sanctions.

As far back as 2008, at the start of the crisis, Connecticut ${ }^{91}$ became

87 Nonetheless, some U.S. jurisdictions have apparently acted in good faith in introducing programs of mandatory mediation, due to the poor indices of adhesion to voluntary mediation: "U.S. courts and legislatures have had little problem in requiring parties to participate in the "voluntary" process of mediation, and in some jurisdictions they must do so in good faith" Ibidem

88 QUEK, Dorcas. op.cit.

89 "More than 25 foreclosure mediation programs have been created in at least 14 states. Although many programs are still finding their footing, outcomes from several established programs are impressive, with some boasting 70-75 percent settlement rates with approximately 60 percent of homeowners reaching settlements that allow them to remain in their homes" Available at: $<$ http://www. http://portal.hud.gov>

90 The States of Connecticut, California, New York, Florida, Pennsylvania, Philadelphia e Rhode Island have adopted mandatory mediation. States and cities such as Delaware, Hawaii, Illinois, Indiana, Kentucky, Maryland, Maine, Michigan, Nevada, New Jersey, New Hampshire, New Mexico, Ohio, Oregon, Minnesota, Wisconsin have adopted voluntary programs. The Wall Street Journal. Dec 2010.

91 "Mediation in Connecticut is available for any qualifying mortgage, which includes both 
one of the first States to approve a law requiring mediation between borrowers in difficulties and creditors, followed by Philadelphia (2008), New York (2008), Florida (2009), California (2009), Rhode Island (2009) and Pennsylvania (2010).

Borrowers always complained of difficulties in negotiating a modification of the amounts due on the loans, an almost always frustrating experience, as they would often receive contradictory information from the representatives of the banks. The work of the mediator in these cases is to balance the forces in conflict, humanizing what is already a most painful process; many homeowners at the risk of losing their homes are managing through mediation to construct solutions for the problem, preventing seizures and reducing the costs of foreclosure. The results are still coming in, yet some figures require attention $^{92}$.

The programs of mediation in New York and Connecticut are indicated as references of success. In Connecticut around 70\% of debtors have entered the mediation program and some $60 \%$ have managed to reduce the monthly payment on their mortgages, whereas in Nevada and New Jersey, where attendance at sessions of mediation is voluntary, $11 \%$ and $20 \%$ of debtors, respectively, have contacted the program. However, what is surprising is that in Nevada, debtors have managed to reach agreements to reduce installments in $74 \%$ of the

first and second liens on any one-to-four family owner-occupied property. Eligible defaulted mortgages are not limited to mortgages taken out for the purchase of the property and can be loans for "personal, family or household purposes", such as refinancing, second mortgages, and home equity lines of credit. Connecticut is a judicial foreclosure state, so homeowners receive notice with service of the complaint on a form titled, 'Notice to Homeowner: Availability of Foreclosure Mediation.' The form lists the eligibility criteria and explains that "Mediation is a process by which a neutral mediator assists parties in trying to reach a voluntary negotiated settlement to resolve their dispute." The form also notes that a homeowner must fill out to participate. The notice ends with a statement in bold that there is no fee for applying to the program. The court must schedule mediation within 10 business days of the homeowner's response. Mediation must conclude within 60 days, though parties or the mediator can apply for a 10-day extension upon a showing of good cause. Bill number 619 would give the court 15 days to schedule mediation and provide for an extension of 30 days. The homeowner and servicer's counsel must appear in person; servicer's counsel must have authority to enter into a settlement, and the servicer's representative must be available by telephone or electronic means. Within two days after the first mediation, the mediator must decide whether a further mediation would be fruitful and send the court and parties a report to that effect; otherwise the mediator may cancel any subsequent sessions and permit foreclosure to proceed. The foreclosure proceedings are not stayed during mediation, so a homeowner must file an answer and participate in the litigation as needed. However, no judgment can be entered until the mediation period has ended." Available at: <http://www.americanprogress.org $>$. Acces on: Aug 102012

92 See: http://www.mediate.com 
cases and in New Jersey $65 \%$.

We note that the index of results favorable to the debtors is greater when participation in mediation is voluntary. And why does the choice of the program have a low index? Lack of knowledge by the debtors about the existence of the programs and the belief that the method is ineffective are convincing reasons.

The complexity and sensitivity required by conflicts thrown up by the mortgage crisis was determinant for the highlight given to them in this article.

Many Americans went through the agony of the risk of losing their homes, and on top of this, the cost that foreclosures represented, not only for the victims, but also for the Government, was expressive. Encouraging the setting-up of programs of mediation and participation by debtors and creditors is a step forward. Extensive publicity for the benefits of mediation would avoid the imposition and the time that the parties have taken to reach an agreement in places where it is mandatory.

Even through the paramount objective of the plan was calling the banks for a settlement, rather than the debtors, since the former would be in a far better position to withstand lengthy lawsuits, even so, it is expected that at least the imposition of mediation is done temporarily, and not installed definitively to the detriment of clarification and education towards reaching an agreement with security and quality.

\section{CLOSING REMARKS}

Mediation, imbued with the social function required of legal mechanisms, has impregnated the contemporary movement for access to justice, and has been occupying a prominent place in the legal systems. It is a process that has undisputed benefits including its voluntary and consensual nature, plus the self-determination of the party, but has been promoted and delivered unequally in both civil law and common law jurisdictions.

It is quite true that we must not allow the Judiciary to be used, abused or manipulated at the whim of the litigants who quite simply want to fight ${ }^{93}$ or take the conflict to new frontiers. We believe that all those who operate the law have already come across a case in which this was clear and, quite often, the judge becomes a hostage to the whim of one or both the parties by virtue of the non liquet Principle.

93 "what people bring to court is the refuse of our national and community life. Mendacity, greed, brutality, sloth, and neglect are the materials with which we work". Paul D Carrington, 'Teaching Civil Procedure: A Retrospective View' (1999) 49 Jo of Leg Educ 311, at 328, apud ANDREWS, Neil. Mediation in England: organic growth and stately progress. Text not yet published and kindly ceded by the author at the time of his visit to the UERJ Law School in December 2011, p. 17. 
The mediation programs have been widely incorporated into the courts; their procedures are regulated by laws, and the participation in the sessions is compulsory in certain subjects. However, the institutionalization and mandatory participation in sessions of mediation, although they may seem to be speedy and efficient solutions, are in actual fact, schemes that compromise the very essence of the mechanism, even on the argument that it is a form of educating the people $^{94}$ and implementing a new form of public policy, and lend themselves to resolve the crisis in access to justice only in the short term.

Leaving mediation in the shadow of a Court or punishing parties who resist the invitation to mediate wounds its identity by bringing it closer to adjudication (proceduralization) or confusing it with conciliation (materialization). In both cases the end result falls short of the expectations.

It is not rational to transform mediation into a remedy to cure the inefficiency of the public administration, making it a measure that restricts access to the court on the legitimizing grounds of ensuring a swifter settlement of disputes. This paradoxical idea has enjoyed priority in many countries.

The EU advances with application of the Directive and the member-states run up against the challenges of establishing programs of mediation, such as the concern with ethics, which becomes stricter in countries that decide to adopt mandatory mediation. Brazil, with no tradition in the use of ADRs, recognizes their importance on the contemporary scene and institutionalizes them in the project for its new Code of Civil Procedure, making them part of the legal landscape. In the U.S.A., where ADRs enjoy greater popularity, it has not been possible to escape the trend heading towards institutionalization and mandatory imposition.

However, we must be cautious about the expectations of

94 "Potential litigants have become aware that mediation can secure various economic gains, social benefits, and even psychological advantages, when compared to the other two main 'paths of justice', namely court proceedings and arbitration. 5 The following points will be uppermost in the minds of disputants when they peer down the barrel of court proceedings: (1) the perception (and nearly always the reality) that court litigation is unpredictable; (2) the judicial process (including extensive preparation for the final hearing) involves a heavy-handed fight for justice, which is a source of expense, delay, and anxiety; (3) court litigation offers little scope for direct participation by the parties, as distinct from legal representatives; (4) final judgment normally awards victory to only one winner; (5) trial is open-air justice, visible to mankind in general; (6) litigation is private war - even if judges pretend that it is governed by elaborate rules and conciliatory conventions designed to take the sting out of the contest". ANDREWS, Neil. (translation. Teresa Alvim Arruda Wambier). O Moderno Processo Civil: formas judiciais e alternativas de resolução de conflitos na Inglaterra, São Paulo: Revista dos Tribunais, 2009, p. 273. 
mediation as a panacea for the shortcomings of the systems of justice. The Judiciary Branch, in its turn, must be allied to the programs of mediation and do not absorb them. If access to justice includes access to systems of ADR, it is fundamental to bear in mind the values that made mediation, in particular, so attractive.

\section{REFERENCES}

ALEMANHA. Bundesgesetzblatt Jahrgang 2012 Teil I nr. 35, aausgegeben zu bonn am 25. Juli 2012. Disponível em: <http://www. bundesgesetzblatt.de $>$. Acesso em 26/07/2012.

ALEXANDER, Nadja. Global Trends in Mediation. New York: Kluwer Law International, 2006.

ANDREWS, Neil. (trad. Teresa Alvim Arruda Wambier). O Moderno Processo Civil: formas judiciais e alternativas de resolução de conflitos na Inglaterra. São Paulo: Revista dos Tribunais, 2009.

ALFINI, James J., et.al. What Happens When Mediation is Institutionalized? Ohio State Journal on Dispute Resolution, vol. 9, nº . 307. 1994.

BAUMAN, Zygmunt. Em busca da política. Rio de Janeiro: Jorge Zahar editor, 2000.

BESSO, Chiara (org). La Mediazione Civile e Commercial, Torino: Giappichelli, 2010.

. La Mediazione Italiana: Definizioni e Tipologie. Revista

Eletrônica de Direito Processual. vol. VI, jul-dez. 2010.

BOBBIO, Norberto. O Positivimo Jurídico. Lições de Filosofia do Direito. São Paulo: Ícone, 2006.

BRASIL. Senado Federal. Projeto de Lei $n .^{o} 8046 / 10$, Brasília, DF, 2010. Disponível em: <http://www.camara.gov.br>.

CAMBI, Eduardo. Neoconstitucionalismo e Neoprocessualismo. 2 ed, São Paulo: Revista dos Tribunais, 2010.

CANOTILHO, José Joaquim Gomes. Direito Constitucional. 6 ed, Coimbra: Almedina Editora, 1993.

CHASE, Oscar G. Law, Culture, and Ritual: Disputing Systems in Cultural Context. New York University Press, 2005.

. American "Exceptionalism" and Comparative Procedure.

American Journal of Comparative Law, nov. 2001.

DITTRICH, Lotario. Il procedimento di mediazione nel d. lgs. $n$. 28, del 4 marzo 2010. Disponível em: <http://www.judicium.it>. Acesso em 20 de outubro de 2011.

ESPANHA. Departament de Justicía de la Generalitat de Catalunya. Ley 15/2005. Exposición de motivos. Modifica el Código Civil y la Ley de Enjuiciamiento Civil en materia de separación y divorcio. Madrid, 2005. Disponível em: <http://civil.udg.es/normacivil/estatal/familia/ 
115-05.htm> Acesso em 15/02/12.

ESPANHA. Ley 5/2012. Regulamenta a mediação em matéria civil e comercial. Boletín Oficial Del Estado. Madrid, 6 de março 2012. p. 18783.

FISS, O.M. Against Settlement, 93 Yale Law Journal 1073-90, may. 1984.

. Alternative Dispute Resolutions Debated: Second-Hand Justice? The Connecticut Law Tribune, March 17. 1986.

FRANÇA. Décret n 2012-66 du 20 janvier 2012. Relatif à la résolution amiable des différends. Journal officiel de la République Française, Paris, 22 janeiro 2012, ${ }^{\circ} 0019$, p. 1280.

FULLER, Lon. Mediation. Its Forms and Functions, Cal. L. Rev. vol. 305, 1971.

GABBAY, Daniela Monteiro. Mediação \& Judiciário: condições necessárias para a institucionalização dos meios autocompositivos de solução de conflitos. 2011. Tese doutorado em Direito - Faculdade de Direito, Universidade de São Paulo, São Paulo, 2011.

ITÁLIA. Decreto Legislativo, 4 marzo 2010. Attuazione dell'articolo 60 della legge 18 giugno 2009, n. 69, in materia di mediazione finalizzata alla conciliazione delle controversie civili e commerciali. Gazzetta Ufficiale, Roma, 4 marzo 2010.

KIRMAYER, Kathryn; WESSEL, Jane. An offer one can't refuse: mediate. The National Law Journal, out. 2004.

LANDE, John. How Will Lawyering and Mediation Practices Transform Each Other? Fla. St. U. L. Rev., 1997,pp. 839, 841.

MUÑOZ, Helena S.. La mediación: método de resolución alternativa de conflictos en el proceso español. Revista Eletrônica de Direito Processual Civil. vol. III, p. 66-88, jan-jun. 2009.

NALINI, José Renato. Os três eixos da Reforma do Judiciário. Revista do Advogado (AASP), n. 75, abr. 2004.

NOLAN-HALEY, Jacqueline M. Evolving Paths to Justice: Assessing the EU Directive on Mediation. Proceedings of the sixth annual conference on international arbitration and mediation. New York: Martinus Nijhof Publishers, 2011.

. The Merger of Law and Mediation: Lessons from Equity Jurisprudence and Roscoe Pound. Cardozo Journal of Dispute Resolution. vol. 6, 2004.

Law Review, 2010.

Mediation: The 'New Arbitration'. Harvard Negotiation

Is Europe Headed Down the Primrose Path with Mandatory Mediation? North Carolina Journal of International Law and Commercial Regulation. vol. 37, 2012.

NOZICK, Robert. Anarquia, Estado e Utopia. Tradução Ruy Jungman. Rio de Janeiro: Zahar Editor, 1994. 
O’CONNEL, Vanessa. Mandatory Mediation in Italy? Mamma Mia! The Wall Street Journal, March, 14. 2011. Disponível em: <http:// wsj. com/law/2011/03/14/mandatory-mediation-in-italy-not-if-the-lawyershave-any-say> Acesso em: 02/08/2012.

OST, François. Contar a Lei. As fontes do imaginário jurídico. Rio Grande do Sul: Unisinos, 2004.

PANTOJA, Fernanda Medina. Mediação Judicial, in: PINHO, Humberto Dalla Bernardina de (orga $\neg$ ni $\neg$ za $\neg$ dor). Teoria Geral da Mediação à luz do Projeto de Lei e do Direito Comparado. Rio de Janeiro: Lumen Juris, 2008.

PAUMGARTTEN, Michele. O processo interativo de construção de soluções como via de reabilitação do sistema vindicativo. Revista Eletrônica de Direito Processual Civil. vol IX, p.552-570. 2012.

PIECKOWSKI, Sylwester. How the New Polish Civil Mediation Law Compares with the Proposed EU Directive on Mediation. Dispute Resolution Journal, n. 67, 2006.

PINHO, Humberto Dalla Bernadina de. Mediação e o CPC Projetado. Revista de Processo. v. 207. 2012.

. A procedural Reading of human rights: the fundamental right to proper protection and the option for mediations a legitimate route for the resolution of conflicts. Revista Juridica Universidad Interamericana de Puerto Rico, vol. XLIV, n 3, agosto-mayo, 2009-2010, p. 545/560.

Mediação: a redescoberta de um velho aliado na solução de conflitos, in: Acesso à Justiça: efetividade do processo (org. Geraldo Prado). Rio de Janeiro: Lumen Juris, 2005, pp. 108.

; PAUMGARTTEN, Michele. L'esperienza italo-brasiliana nell'uso della mediazione in risposta alla crisi del monopolio statale di soluzione di conflitti e la garanzia di accesso alla giustizia. Revista de Direitos e Garantias Fundamentais FDV, n. 11, pp. 171-201, ago. 2012. PRESS, Sharon. Institutionalization: Savior or Saboteur of Mediation? Florida State University Law Review. vol. 24. 1997.

. Court-Connected Mediation and Minorities: A Report Card. Capital University Review. vol. 39. 2011.

Mortgage Foreclosure Mediation in Florida Implementation Challenges for an Institutionalized Program. Nevada Law Review. vol. 11, Spring 2011.

RAY, Brian. Extending the shadow of the law: using hybrid mechanisms to develop constitutional norms in socioeconomic rights. Utah Law Review. n. 3, pp. 797-842, 2006.

RESTA, Eligio. Il Diritto Fraterno. Roma: Laterza, 2010.

SCHENK, Leonardo. Breve relato histórico das reformas processuais na Itália. Um problema constante: a lentidão dos processos cíveis. Revista Eletrônica de Direito Processual, Rio de Janeiro, v. 2, p. 181202, 2008. Disponível em: http://www.redp.com.br/edicao_02.htm. 
Acesso em: 10/08/2012.

TARUFFO, Michele. Cultura e processo. Rivista Trimestrale di Diritto e Procedura Civile. Milano: Giuffrè Editore, 2009.

. Dimensioni transculturale della giustizia civile. Rivista Trimestrale di Diritto e Procedura Civille, dez. 2007.

UNIÃO EUROPÉIA. Diretiva 2008/52/CE, de 21 de maio de 2008. Jornal Oficial da União Européia, Parlamento Europeu e do Conselho, Bruxelas, 24 maio 2008.

VIGORITI, Vincenzo. Europa e mediazione. Problemi e soluzioni. Revista de Processo. n. 197. 2011.

WARAT, Luis Alberto. O oficio do mediador, v. 1. Florianópolis: Habitus, 2001.

WINKLER, K. Warren. Accès à la Justice: la mediation judiciaire. Canadian Arbitration and Mediation Journal. n. 16, p. 9-12. 2007. 